\title{
SISTEM INFORMASI MANAJEMEN SURAT BERBASIS PHP DAN MYSQL DI INSTITUT SENI INDONESIA PADANGPANJANG
}

\author{
Irwan Yusti \\ Program Studi Sistem Informasi Sekolah Tinggi Teknologi Industri (STTIND) Padang \\ email: irwan_yusti@yahoo.com
}

\begin{abstract}
Administrative services mail at ISI Padangpanjang still use the procedures manual by recording the letter into an agenda book, followed by the processing stages of each leader to leader next, this process is done manually by the staff of managers by delivering direct mail to any room leaders and stakeholders, so that the effectiveness of the service is not optimal. Under these conditions made a management information system based mail web using the programming language PHP with MySQL database, the system is built with a user interface design that allows users, processing a letter centered on a database, so that the flow of execution and processing letter will be more quickly and precisely, with The processing system built at ISI Padangpanjang letters of administration will be more effective and can save paper usage.
\end{abstract}

Keywords: Information Systems, PHP, database, MySQL, mail processing

\section{Pendahuluan}

\subsection{Latar Belakang Masalah}

Didalam sebuah organisasi surat menjadi sesuatu yang sangat penting serta dibutuhkan pengadminstrasian serta pengelolaan menajemen persuratan yang baik, tertata, terarah, terstruktur dan terorganisasi dengan baik, kerena dalam sebuah organisasi baik swasta ataupun pemerintahan sebuah surat akan memiliki nilai yang sangat penting dan bahkan dapat mempengaruhi maju mundurnya sebuah organisasi, serta menjadi bukti tertulis sebagai dokumen penting bagi organisisai serta kepentingan-kepentingan stakeholder yang berhubungan langsung atau tidak langsung dengan organisasi.

Dalam melakukan pengelolaan dan pengadministrasian surat menyurat instansi pemerintah perpedoman kepada Peraturan Menteri Pendayagunaan Aparatur Negara dan Reformasi Birokrasi nomor 80 tahun 2012 tentang Pedoman Tata Naskah Dinas Instansi Pemerintah.

Institut Seni Indonesia Padangpanjang sebagai salah satu satuan kerja di lingkup Kementerian Pendidikan dan Kebudayaan dalam melakukan pengelolaan dan pengadministrasian dan ketatausahaan juga mengacu kepada Peraturan Meneteri Aparatur Negara dan Reformasi Birokrasi nomor 80 tahun 2012 tentang Pedoman Tata Naskah Dinas Instansi Pemerintah serta peraturan internal dari Kementerian Pendidikan dan
Kebudayaan nomor 6 Tahun 2013 tentang Tata Naskah Dinas dilingkungan Kementerian Pendidikan dan Kebudayaan.

Berdasarkan penelitian awal penulis di subbag Tata Usaha, Tata Laksana Humas serta kesekretariatan sebagai unit pengelola tata naskah dinas dan persuratan di Institut Seni Indonesia (ISI) Padangpanjang, dapat digambarkan proses dan prosedur pengelolaan tata naskah dinas terutama pengolahan surat masuk dan surat keluar secara terstruktur telah mengikuti kaidah dan aturan yang berlaku, permasalahan yang sering kali muncul adalah ketika proses pencarian serta status keberadaan surat serta informasi tentang tindak lanjut terhadap surat masuk ataupun keluar, seringkali sekretariat harus berkali-kali membuka buku agenda hanya untuk mencari satu buah nomor surat, hal ini disebabkan pencatatan agenda surat masih dilakukan secara manual ditulis tangan kedalam buku agenda.

Sesuai dengan asumsi dan penelitian awal maka penulis mencoba membuat sebuah program sistem informasi pengelolaan surat yang nantinya dapat menjadi alat bantu sub bagian tata usaha, tata laksana dan humas ISI Padangpanjang dalam memberikan layanan administrasi persuratan yang lebih baik kepada semua stakeholder ISI Padangpanjang dengan judul penelitian "Sistem Informasi Manajemen Surat berbasis PHP dan Mysql di Insitut Seni Indonesia Padangpanjang”. 


\subsection{Identifikasi Masalah}

Dalam melakukan penelitian penulis menemukan beberapa permasalahan yang dihadapi dalam melakukan pengelolaan surat di ISI Padangpanjang adalah sebagai berikut :

a. Proses pengelolaan dan pencatatan agenda surat masih dilakukan secara manual dan sulit untuk melakukan pencarian surat kembali.

b. Distribusi proses pengelolaan, tindak lanjut dan aksi pelaksanaan memakan waktu yang panjang.

c. Membutuhkan biaya penggunaan Alat Tulis Kantor yang cukup banyak.

\subsection{Batasan Masalah}

Batasan masalah dalam penulisan ini adalah menyiapkan dan membuat sebuah sistem informasi dan alat bantu bagi subbag pengelola dan pengolah surat sehingga memberikan kemudahan dalam melakukan pelayanan administrasi surat masuk dan keluar.

\subsection{Rumusan masalah}

Rumusan masalah dalam penulisan ini adalah bagaimana membangun sebuah program aplikasi sistem informasi dan aplikasi menajemen surat berbasis aplikasi web dengan PHP dan Mysql.

\subsection{Tujuan Penelitian}

Tujuan dari penelitian ini adalah sebagai berikut :

1. Membuat sebuah program aplikasi sistem informasi manajemen surat berbasis web dengan PHP dan Mysql.

2. Sistem Informasi Manajemen surat yang dibuat dapat menggantikan fungsi buku agenda manual sebagai pencatat transaksi pengolahan surat.

3. Sistem yang dibangun diharapkan dapat meminimalkan biaya penggunaan dan pembelian Alat Tulis Kantor.

\subsection{Manfaat Penelitian}

Manfaat yang diharapkan dari sistem yang dibangun adalah sebagai berikut :

a. Pegawai dan Sub bagaian Tatat Usaha, Tata Kelola dan Humas sebagai pengelola surat.

Dengan adanya sistem yang berbasis database dan interface / tampilan antar muka yang menarik dan mudah digunakan akan lebih memudahkan pegawai dalam melakukan pengolahan surat serta pencarian surat kembali pada saat dibutuhkan.

b. Institusi

Proses pengelolaan dan pengolahan surat yang baik dan tersistematik akan memudahkan lembaga dan institusi memberikan layanan yang maksimal kepada pengguna jasa institusi sekaligus memberikan brand dan citra yang baik terhadap institusi karena setiap proses administrasi sudah terkomputerisasi dan tersistem dengan baik.

c. Diri Pribadi

Sebagai bentuk pembelajaran dan transfer ilmu yan telah penulis dapatkan selama menempuh pendidikan program S1 Sistem Informasi Sekolah Tinggi Teknologi Industri (STTIND) Padang.

\section{Landasan Teori}

\subsection{Konsep Dasar Sistem}

Terdapat dua kelompok pendekatan di dalam mendefinisikan sistem, yaitu yang menekankan pada prosedurnya dan yang menekankan pada komponen atau elemennya. Pendekatan sistem yang lebih menekankan pada prosedur sistem adalah sebagai berikut:

"Sistem adalah suatu jaringan kerja dari prosedur-prosedur yang saling berhubungan, berkumpul bersama-sama untuk melakukan suatu kegiatan atau untuk menyelesaikan suatu sasaran tertentu."

Pada dasarnya, sistem adalah sekumpulan elemen yang saling terkait atau terpadu yang dimaksudkan untuk mencapai suatu tujuan. Sebagai gambaran, jika dalam sebuah sistem terdapat elemen yang tidak memberikan manfaat dalam mencapai tujuan yang sama, maka elemen tersebut dapat dipastikan bukanlah bagian dari sistem (Abdul Kadir, 2003,10).

\subsection{Konsep Dasar Sistem Informasi}

Sistem informasi didefinisikan oleh Abdul Kadir dalam bukunya Pengenalan Sistem Informasi sebagai berikut:

"Sistem informasi mencakup sejumlah komponen (manusia, komputer, teknoloi informasi, dan prosedur kerja), ada sesuatu yang diproses (data menjadi informasi), dan dimaksudkan untuk mencapai suatu sasaran atau tujuan.". 


\section{a. Blok Masukan}

Masukan atau Input mewakili data yang masuk ke dalam sistem informasi. Masukan disini termasuk metode-metode dan media untuk menangkap data yang akan dimasukkan, yang dapat berupa dokumendokumen dasar.

\section{b. Blok Model}

Blok ini terdiri dari kombinasi prosedur, logika dan model matematik yang akan memanipulasi data input dan data yang tersimpan di basis data dengan cara yang sudah ditentukan untuk menghasilkan keluaran yang diinginkan.

\section{c. Blok Keluaran}

Produk dari sistem informasi adalah keluaran yang merupakan informasi yang berkualitas dan dokumentasi yang berguna untuk semua tingkatan manajemen serta semua pemakai sistem.

\section{d. Blok Teknologi}

Teknologi merupakan "kotak alat" (toolbox) dalam sistem informasi. Teknologi digunakan untuk menerima input, menjalankan model, menyimpan dan mengakses data, menghasilkan dan mengirimkan keluaran dan membantu pengendalian dari sistem secara keseluruhan.

\section{e. Blok Basis Data}

Basis data (database) merupakan kumpulan dari data yang saling berhubungan satu dengan lainnya, tersimpan di perangkat keras komputer dan digunakan perangkat lunak untuk memanipulasinya. Data perlu disimpan di dalam basis data untuk keperluan penyediaan informasi lebih lanjut. Data di dalam basis data perlu diorganisasikan sedemikian rupa, supaya informasi yang dihasilkan berkualitas. Organisasi basis data yang baik juga berguna untuk efisiensi kapasitas penyimpannya. Basis data diakses atau dimanipulasi dengan menggunakan perangkat lunak paket yang disebut dengan DBMS (Database Management Systems).

\section{f. Blok Kendali}

Banyak hal yang dapat merusak sistem informasi, seperti misalnya bencana alam, api, temperatur, air, debu, kecurangan-kecurangan, kegagalan-kegagalan sistem itu sendiri, kesalahan-kesalahan, ketidak-efisienan, sabotase, dan lain sebagainya. Beberapa pengendalian perlu dirancang dan diterapkan untuk meyakinkan bahwa hal-hal yang dapat merusak sistem dapat dicegah ataupun bila terlanjur terjadi kesalahan-kesalahan dapat langsung diatasi.

\subsection{Analisa dan Perancangan Sistem}

Penguraian dari suatu sistem informasi yang utuh ke dalam bagian-bagian komponennya dengan maksud untuk mengidentifikasi dan mengevaluasi permasalahan-permasalahan, kesempatankesempatan, hambatan-hambatan yang terjadi dan kebutuhan-kebutuhan yang diharapkan sehingga dapat diusulkan perbaikanperbaikannya.

Tahap analisis sistem dilakukan setelah tahap perencanaan sistem (system planning) dan sebelum tahap desain sistem (system design). Tahap analisis merupakan tahap yang kritis dan sangat penting, karena kesalahan di dalam tahap ini juga akan menyebabkan kesalahan di tahap selanjutnya.

Menurut Kendall (2003:7) dalam tahap analisis sistem terdapat langkah-langkah dasar yang harus dilakukan oleh analis sistem sebagai berikut:

1. Identify, yaitu mengidentifikasi masalah.

2. Understand, yaitu memahami kerja dari sistem yang ada.

3. Analyze, yaitu menganalisis sistem.

4. Report, yaitu membuat laporan hasil analisis.

Setelah tahap analisis sistem selesai dilakukan, maka analis sistem telah mendapatkan gambaran dengan jelas apa yang harus dikerjakan. Tiba waktunya sekarang bagi analis sistem untuk memikirkan bagaimana membentuk sistem tersebut. Tahap ini disebut dengan desain sistem.

Menurut Kendall (2003:7), Analisa dan Perancangan Sistem dipergunakan untuk menganalisis, merancang, dan mengimplementasikan peningkatanpeningkatan fungsi bisnis yang dapat dicapai melalui penggunaan sistem informasi terkomputerisasi.

\section{System Flow}

System flow atau bagan alir sistem merupakan bagan yang menunjukkan arus pekerjaan secara keseluruhan dari sistem. System flow menunjukkan urutan-urutan dari prosedur yang ada di dalam sistem dan 
menunjukkan apa yang dikerjakan sistem. Simbol-simbol yang digunakan dalam system flow ditunjukkan pada gambar berikut

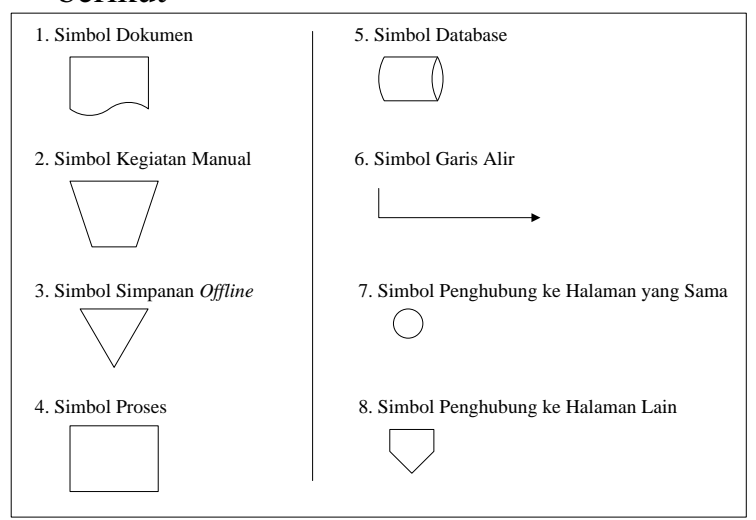

Gambar 1. Simbol-simbol pada Aliran Sistem Informasi

\section{Data Flow Diagram (DFD)}

DFD sering digunakan untuk menggambarkan suatu sistem yang telah ada atau sistem baru yang akan dikembangkan secara logika tanpa mempertimbangkan lingkungan fisik dimana data tersebut mengalir. DFD merupakan alat yang digunakan pada metodologi pengembangan sistem yang terstruktur dan dapat mengembangkan arus data di dalam sistem dengan terstruktur dan jelas.

\section{Simbol-simbol yang digunakan dalam DFD}

\section{a. External Entity atau Boundary}

External entity atau kesatuan luar merupakan kesatuan di lingkungan luar sistem yang dapat berupa orang, organisasi atau sistem lainnya yang berada di lingkungan luarnya yang akan memberikan input atau menerima output dari sistem. External entity disimbolkan dengan notasi kotak.

\section{b. Arus Data}

Arus Data (data flow) di DFD diberi simbol panah. Arus data ini mengalir di antara proses, simpanan data (data store) dan kesatuan luar (external entity). Arus data ini menunjukkan arus data yang dapat berupa masukan untuk sistem atau hasil dari proses sistem.

c. Proses

Suatu proses adalah kegiatan yang dilakukan oleh orang, mesin, atau komputer dari hasil suatu arus data yang masuk ke dalam proses untuk menghasilkan arus data yang akan keluar dari proses. Simbol proses berupa lingkaran atau persegi panjang bersudut tumpul.

\section{d. Simpanan Data}

Simpanan data merupakan simpanan dari data yang dapat berupa hal-hal sebagai berikut, sebagai gambaran:

1. Suatu file atau database di sistem komputer.

2. Suatu arsip atau catatan manual.

3. Suatu kotak tempat data di meja seseorang.

4. Suatu tabel acuan manual.

Simpanan data di DFD disimbolkan dengan sepasang garis horizontal paralel yang tertutup di salah satu ujungnya.

\section{Context Diagram}

Context Diagram merupakan langkah pertama dalam pembuatan DFD. Pada context diagram dijelaskan sistem apa yang dibuat dan eksternal entity apa saja yang terlibat. Dalam context diagram harus ada arus data yang masuk dan arus data yang keluar.

\section{Data Flow Diagram Level 0}

DFD level 0 adalah langkah selanjutnya setelah context diagram. Pada langkah ini, digambarkan proses-proses yang terjadi dalam sistem informasi.

\section{Data Flow Diagram Level 1}

DFD Level 1 merupakan penjelasan dari DFD level 0. Pada proses ini dijelaskan proses apa saja yang dilakukan pada setiap proses yang terdapat di DFD level 0 .

\section{Entity Relational Diagram}

Entity Relational Diagram (ERD) merupakan penggambaran hubungan antara beberapa entity yang digunakan untuk merancang database yang akan diperlukan.

\section{Konsep Dasar Basis Data}

\section{Database}

Menurut Abdul Kadir (2003:254), database adalah suatu pengorganisasian sekumpulan data yang saling terkait sehingga memudahkan aktivitas untuk memperoleh informasi

Penyusunan satu database digunakan untuk mengatasi masalah-masalah pada penyusunan data yaitu redundansi dan inkonsistensi data, kesulitan pengaksesan data, isolasi data untuk standarisasi, multiple user (banyak pemakai), masalah 
keamanan (security), masalah integrasi (kesatuan), dan masalah data independence (kebebasan data).

\section{a. Sistem Basis Data}

Menurut Abdul Kadir (2003:254), sistem basis data adalah perangkat lunak sistem yang memungkinkan para pemakai membuat, memelihara, mengontrol, dan mengakses basis data dengan cara yang praktis dan efisien, Database Manajemen Sistem (DBMS) dapat digunakan untuk mengakomodasikan berbagai macam pemakai yang memiliki kebutuhan akses yang berbeda beda.

Pada sebuah sistem basis data terdapat komponen-komponen utama yaitu Perangkat Keras (Hardware), Sistem Operasi (Operating System), Basis Data (Database), Sistem (Aplikasi atau Perangkat Lunak) Pengelola Basis Data(DBMS), Pemakai (User), dan Aplikasi (Perangkat Lunak) lain (bersifat opsional).

b. Kelebihan Sistem Basis Data

1. Mengurangi kerangkapan data, yaitu data yang sama disimpan dalam berkas data yang berbeda-beda sehingga update dilakukan berulang-ulang.

2. Mencegah ketidakkonsistenan.

3. Keamanan data dapat terjaga, yaitu data dapat dilindungi dari pemakai yang tidak berwenang.

4. Integritas dapat dipertahankan.

5. Data dapat dipergunakan bersamasama.

6. Menyediakan recovery.

7. Memudahkan penerapan standarisasi.

8. Data bersifat mandiri (data independence).

9. Keterpaduan data terjaga, memelihara keterpaduan data berarti data harus akurat. Hal ini sangat erat hubungannya dengan pengontrolan kerangkapan data dan pemeliharaan keselarasan data.

\section{c. Kekurangan Sistem Basis Data}

1. Diperlukan tempat penyimpanan yang besar.

2. Diperlukan tenaga yang terampil dalam mengolah data.

3. Kerusakan sistem basis data dapat mempengaruhi departemen yang terkait.

\section{d. Database Management System}

Menurut Abdul Kadir (2003:254), Database Management System (DBMS) data adalah perangkat lunak sistem yang memungkinkan para pemakai membuat, memelihara, mengontrol, dan mengakses basis data dengan cara yang praktis dan efisien, Database Manajemen Sistem (DBMS) dapat digunakan untuk mengakomodasikan berbagai macam pemakai yang memiliki kebutuhan akses yang berbeda beda

e. Bahasa-bahasa yang terdapat dalam DBMS

1. Data Definition Language (DDL)

Pola skema basis data dispesifikasikan dengan satu set definisi yang diekspresikan dengan satu bahasa khusus yang disebut DDL. Hasil kompilasi perintah DDL adalah satu set tabel yang disimpan di dalam file khusus yang disebut data dictionary/directory.

2. Data Manipulation Language (DML) Bahasa yang memperbolehkan pemakai mengakses atau memanipulasi data sebagai yang diorganisasikan sebelumnya model data yang tepat.

3. Query

Pernyataan yang diajukan untuk mengambil informasi. Merupakan bagian DML yang digunakan untuk pengambilan informasi.

\section{f. Fungsi DBMS}

1. Data Definition DBMS harus dapat mengolah data definition atau pendefinisian data.

2. Data Manipulation

DBMS harus dapat menangani permintaan-permintaan dari pemakai untuk mengakses data.

3. Data Security dan Integrity

DBMS dapat memeriksa security dan integrity data yang didefinisikan oleh DBA.

4. Data Recovery dan Concurrency

a. DBMS harus dapat menangani kegagalan-kegagalan pengaksesan basis data yang dapat disebabkan oleh kesalahan sistem, kerusakan disk, dan sebagainya.

b. DBMS harus dapat mengontrol pengaksesan data yang konkuren yaitu bila satu data diakses secara 
bersama-sama oleh lebih dari satu pemakai pada saat yang bersamaan.

\section{Data Dictionary}

DBMS harus menyediakan

datadictionary atau kamus data.

\section{g. Tool Pemrograman}

Dalam pengembangan suatu sistem informasi, tentunya membutuhkan suatu tool atau alat berupa bahasa pemrograman. Salah satu tool dalam bahasa pemrograman yang dipakai untuk penelitian ini adalah PHP dengan editor yang dipakai Adobe Dreamwafer CS5, NotePad++ dan database MySql.

\section{Tentang PHP}

PHP Pertama kali ditemukan pada 1995 oleh seorang Software Developer bernama Rasmus Lerdrof. Ide awal PHP adalah ketika itu Radmus ingin mengetahui jumlah pengunjung yang membaca resume onlinenya. Script yang dikembangkan baru dapat melakukan dua pekerjaan, yakni merekam informasi visitor, dan menampilkan jumlah pengunjung dari suatu website. Dan sampai sekarang kedua tugas tersebu tmasih tetap popular digunakan oleh dunia web saat ini. Kemudian, dari situ banyak orang dimilis mendiskusikan script buatan Rasmus Lerdrof, hingga akhirnya rasmus mulai membuat sebuah tool/script, bernama Personal Home Page(PHP).

Kebutuhan PHP sebagai tool yang serbaguna membuat Lerdorf melanjutkan untuk mengembangkan PHP hingga menjadi suatu bahasa tersendiri yang mungkin dapat mengkonversikan data yang diinputkan melalui Form HTML menjadi suatu variable, yang dapat dimanfaatkan oleh system lainnya. Untuk merealisasikannya, akhirnya Lerdrof mencoba mengembangkan PHP menggunakan bahasa $\mathrm{C}$ ketimbang menggunakan Perl. Tahun 1997, PHP versi2.0 dirilis, dengan nama Personal Home Page Form Interpreter (PHP-FI). PHP Semakin popular, dan semakin diminati oleh programmer web dunia.

Rasmus Lerdrof benar-benar menjadikan PHP sangat populer,dan banyak sekali Team Developer yang ikut bergabung dengan Lerdrof untuk mengembangkan PHP hingga menjadi seperti sekarang, Hingga akhirnya dirilis versi ke 3-nya, pada Juni 1998, dan tercatat lebih dari 50.000 programmer menggunakan PHP dalam membuat website dinamis.

Pengembangan demi pengembangan terus berlanjut, ratusan fungsi ditambahkan sebagai fitur dari bahasa PHP, dan diawaal tahun 1999, netcraft mencatat, ditemukan 1.000.000 situs di dunia telah menggunakan PHP. Ini membuktikan bahwa PHP merupakan bahasa yang paling popular digunakan oleh dunia web development. Hal ini mengagetkan para developernya termasuk Rasmus sendiri, dan tentunya sangat diluar dugaan sang pembuatnya. Kemudian Zeev Suraski dan Andi Gutsman selaku core developer (programmer inti) mencoba untuk menulis ulang PHP Parser, dan diintegrasikan dengan menggunakan Zend scripting engine, dan mengubah jalan alur operasi PHP. Dan semua fitur baru tersebut dirilis dalam PHP 4.

\section{Keunggulan PHP}

a. Gratis

Apa yang membuat PHP begitu berkembang sangat pesat?, hingga jutaan domain menggunakan PHP, begitupopulernya PHP?, Jawabannya adalah karena PHP itu gratis. Saya sendiri menyukai bahasa yang satu ini selain mudah juga karena gratis.

\section{b. Cross platform}

Artinya dapat digunakan diberbagai system operasi,mulai dari linux, windows, mac os dan os yang lain.

\section{c. Mendukung banyak database}

PHP telah mendukung banyak database,ini mengapa banyak developer web menggunakan PHP AdabasD AdabasD, dBasedBase, EmpressEmpress, FilePro (read-only) FilePro (read-only) Hyperwave, IBMDB2, Informix, Ingres, InterBase, FrontBasemSQL, DirectMSSQL, MySQLMySQL, ODBC, Oracle(OCI7 and OCI8), Ovrimos, Postgre SQL SQLite, Solid, Sybase, Velocis, Unixdbm.

\section{d. On TheFly}

PHP sudah mendukung on the fly, artinya dengan php anda dapat membuat document text,Word, Excel, PDF, menciptakan image dan flash juga menciptakan file-file seperti zip, XML,dan banyak lagi.

3. Model penulisan Tag PHP

Cara pertama di dalam menuliskan script PHP dan yang banyak dipakai pada proses pemograman yaitu : 
$<? \mathrm{php}$

?> isi dari statement yang dibuat

Contoh :

$<$ ?php

Echo "Hallo World";

Echo " $<$ br / $>$ Saya dari script php";

?>

Out put :

Hallo World

Saya dari script php

4. Mysql

a. MySQL adalah Database

Database sendiri merupakan suatu jalan untuk dapat menyimpan berbagai informasi dengan membaginya berdasarkan kategorikategori tertentu. Dimana informasiinformasi tersebut saling berkaitan, satu dengan yang lainnya.

b. MySQL bersifat RDBMS (Relational Database Management System)

RDBMS memungkinkan seorang admin dapat menyimpan banyak informasi ke dalam table-table, dimana table-table tersebut saling berkaitan satu sama lain. Keuntungan RDBMS sendiri adalah kita dapat memecah database kedalam table-table yang berbeda. setiap table memiliki informasi yang berkaitan dengan table yang lainnya.

c. Keunggulan Mysql

1. Gratis

Sama dengan PHP, MySQL bersifat opensource, semua orang bebas menggunakannya tanpa harus membayar sepeserpun

2. Cross Platform MySQ1 dapat digunakan underwindows, ataupun underlinux.

\section{Lengkap dan Cepat}

Pasangan yang cocok dengan PHP. Wajar jika banyak hosting saat ini mendukung adanya PHP dan MySQL karena kecepatan, gratis, dan dapat dijalankan disistem operasi manapun.

\section{Interaksi Manusia dan Komputer}

Suatu Sistem Informasi yang baik tentunya harus mempertimbangkan interaksi antara pengguna dan program yang dibuat. Di sinilah pentingnya penerapan ilmu Interaksi Manusia dan Komputer.

Menurut Rizky (2006:4), Interaksi Manusia dan Komputer (IMK) adalah sebuah disiplin ilmu yang mempelajari desain, evaluasi, implementasi dari sistem komputer interaktif untuk dipakai oleh manusia, beserta studi tentang faktor-faktor utama dalam lingkungan interaksinya.

Deskripsi lain dari IMK adalah suatu ilmu yang mempelajari perencanaan dan desain tentang cara manusia dan komputer saling bekerja sama, sehingga manusia dapat merasa puas dengan cara yang paling efektif. Dikatakan juga bahwa sebuah desain antar muka yang ideal adalah yang mampu memberikan kepuasan terhadap manusia sebagai pengguna dengan faktor kapabilitas serta keterbatasan yang terdapat dalam sistem.

Pada implementasinya, IMK dipengaruhi berbagai macam faktor antara lain organisasi, lingkungan, kesehatan, pengguna, kenyamanan, antar muka, kendala dan produktifitas.

\section{METODOLOGI}

\subsection{Jenis Penelitian}

Jenis penelitian yang digunakan adalah penelitian dengan pendekatan kualitatif dengan mengedepankan penekanan aspek analisis terhadap dinamika hubungan antarfenomena yang diamati atau diteliti dengan menggunakan logika ilmiah. (Saifudin Azwar, MA, 2004 : 3), salah satu ciri khas penelitian kualitatif adalah deskriptif, dimana data yang dikumpulkan adalah berupa kata-kata dan gambar. Data tersebut bisa berasal dari naskah, wawancara, catatan lapangan, foto, model, dokumen pribadi ataupun dokumen resmi lainnya.

\subsection{Objek Penelitian}

Objek dalam penelitian ini yaitu pengelolaan surat masuk dan keluar sebagai suatu bagian proses administrasi dan tata naskah dinas dalam instansi pemerintah.

\subsection{Lokasi dan Waktu Penelitian}

Penelitian ini dilakukan di Institut Seni Indonesia Padangpanjang yang dilaksanakan selama dua bulan yaitu, bulan Mei 2015 sampai dengan bulan Juni 2015. 


\subsection{Teknik Pengumpulan Data}

Metode yang digunakan oleh penulis dalam pengumpulan data pada penelitian ini adalah metode studi kepustakaan atau biasa dikenal dengan istilah library research dan teknik wawancara untuk mengetahui semua kebutuhan user/pengguna terhadap rancangan sistem yang akan ditawarkan. Dengan demikian data-data penelitian tersebut adalah data yang berasal dari wawancara, buku, dokumen, artikel dan lain-lain. Menurut Lofland (1984:47) sumber data utama dalam peneltian kualitatif adalah kata-kata dan tindakan, dalam penelitian ini, data penelitian berasal dari Peraturan Kementerian Pendidikan dan Kebudayaan nomor 6 Tahun 2013 tentang Tata Naskah Dinas dilingkungan Kementerian Pendidikan dan Kebudayaan, Peraturan Rektor Institut Seni Indonesia Nomor tentang dan wawancara peneliti dengan subbag Tata Usaha, Tata Laksana dan Humas sebagai unit terkait pengelolaan administrasi surat di Institut Seni Indonesia Padangpanjang.

Dalam proses pengumpulan data penelitian, penulis melakukan beberapa tahapan sebagai berikut:

\subsubsection{Tahap pertama}

Pada tahap pertama penulis mengumpulkan semua data, berupa motode, tata cara, standarisasi dan model pengelolaan surat sesuai peraturan Kementerian Pendidikan dan Kebudayaan nomor 6 Tahun 2013 tentang Tata Naskah Dinas dilingkungan Kementerian Pendidikan dan Kebudayaan dan Peraturan Rektor ISI Padangpanjang serta melakukan wawancara dengan subbag Tata Usaha, Tata Laksana, dan Humas untuk mendapatkan gambaran awal model dan kebutuhan sistem yang dibutuhkan dengan tetap mengacu kepada model dan aliran sistem yang telah ada, dalam artian sistem ini adalah bentuk penerapan peraturan pengelolaan surat atau naskah dinas ke model program aplikasi komputer sistem informasi manajemen surat.

\subsubsection{Tahap kedua}

Pada tahap ini, penulis melakukan pengklasifikasian terhadap data-data yang telah terkumpul berdasarkan rumusan masalah. Pengklasifikasian data dilakukan dengan cara menyusun data-data yang ada ke bentuk umum rancangan sistem informasi dengan mengacu ke SDLC (System Development Live Cyrcle).

\subsection{Teknik Pengolahan Data}

Data-data yang telah diperoleh pada saat pengumpulan data akan diolah dengan menggunakan metode analisis deskriptif. Dengan menggunakan konsep Siklus hidup pengembangan sistem informasi yang terbagi atas enam fase, yaitu :

a. Perencanaan sistem

b. Analisis sistem

d. Perancangan sistem secara umum/ konseptual

e. Evaluasi dan seleksi sistem

f. Perancangan sistem secara detail

g. Pengembangan Perangkat Lunak dan Implementasi sistem

h. Pemeliharaan/Perawatan Sistem

\section{Hasil dan Pembahasan \\ 4.1 Analisa Sistem \\ Gambaran Umum Sistem}

Sistem yang akan dibuat adalah sistem yang dapat mempermudah bagian Administrasi dalam membuat dan mengolah data-data surat masuk dan surat keluar, membuat disposisi surat masuk, laporan surat masuk dan surat keluar serta mengarsipkan data surat masuk dan surat keluar. Sistem Manajemen Surat ini dapat diakses oleh user yang terdiri dari semua unsur pimpinan pelaksana administrasi, mengakses menu pencarian dan laporan.

Proses surat masuk dan surat keluar yang dilaksanakan oleh subbag Tata Usaha ISI Padangpanjang dapat digambarkan dengan sistem manual yang berjalan pada gambar .2 :

\subsection{Perancangan Sistem}

Berdasarkan analisis sistem yang ada, maka akan dirancang suatu sistem yang sesuai dengan kebutuhan. Rancangan sistem yang dibuat berupa Data Flow Diagram (DFD) sebagai deskripsi alur dari sistem. DFD dibuat dengan menggunakan software Edraw Max 5.0.

\subsubsection{Aliran Sistem Informasi}

Aliran Sistem Informasi atau ASI adalah bagan yang memiliki arus pekerjaan secara menyeluruh dari suatu sistem yang menjelaskan urutan prosedur-prosedur yang terdapat di dalam sistem.

Data Flow Diagram (DFD) yaitu bagan yang memiliki arus data dalam suatu sistem yang telah ada atau system baru yang akan dikembangkan secara logika. 


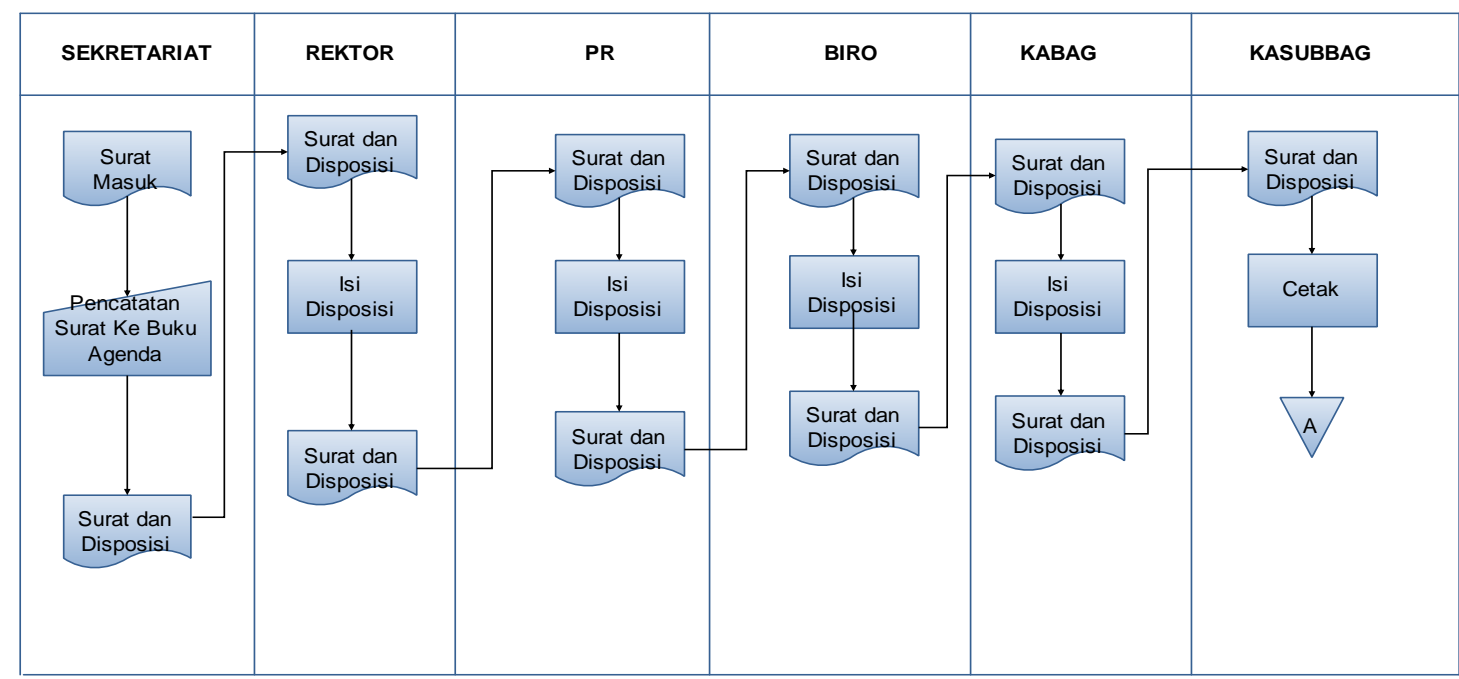

Gambar.2 Aliran Sistem Informasi lama

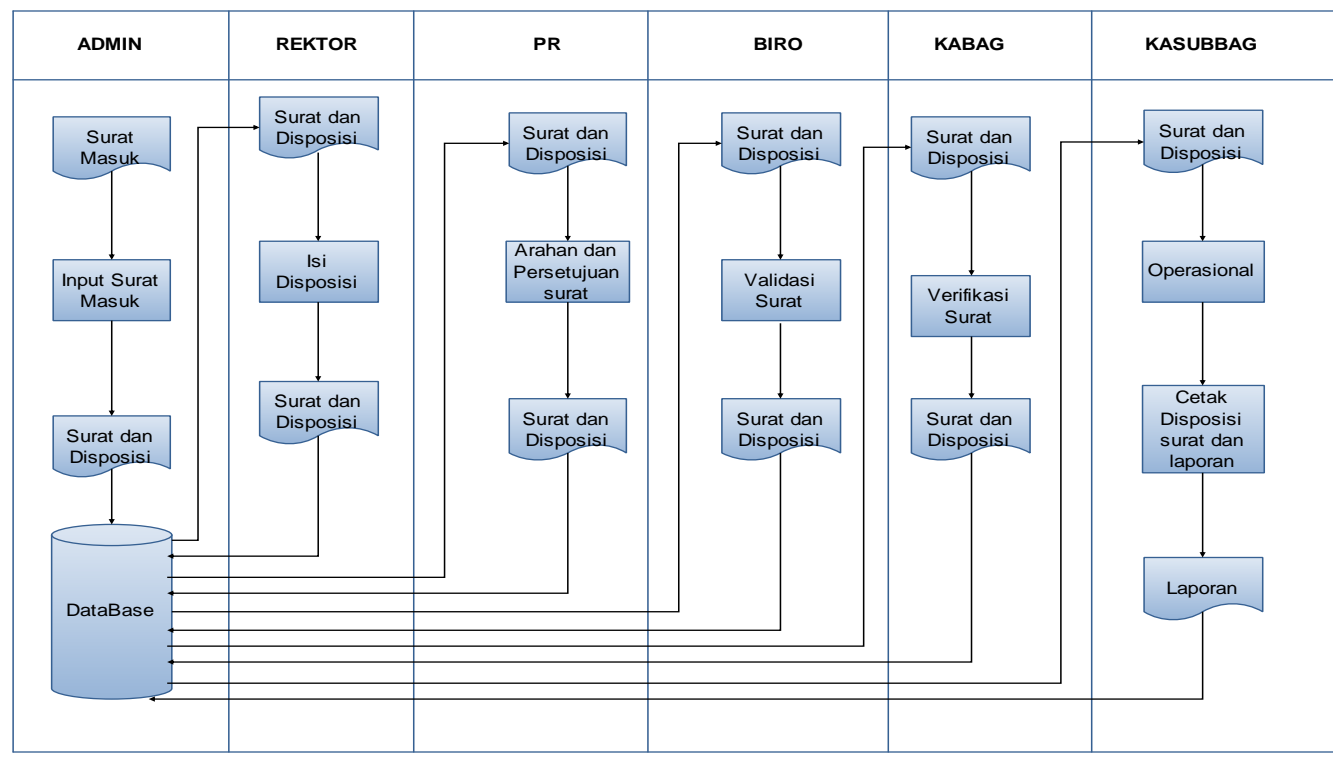

Gambar. 3. Aliran Sistem Informasi yang diusulkan

\section{a. Context Diagram}

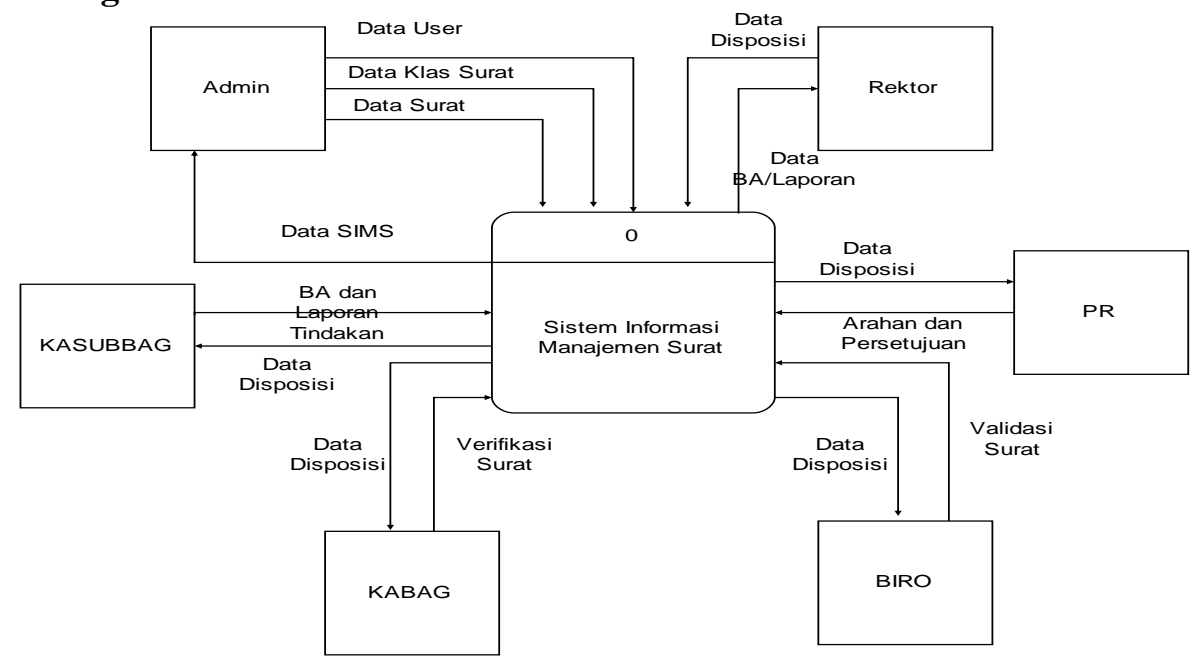

Gambar 4. Context Diagram 


\section{b. Data Flow Diagram}

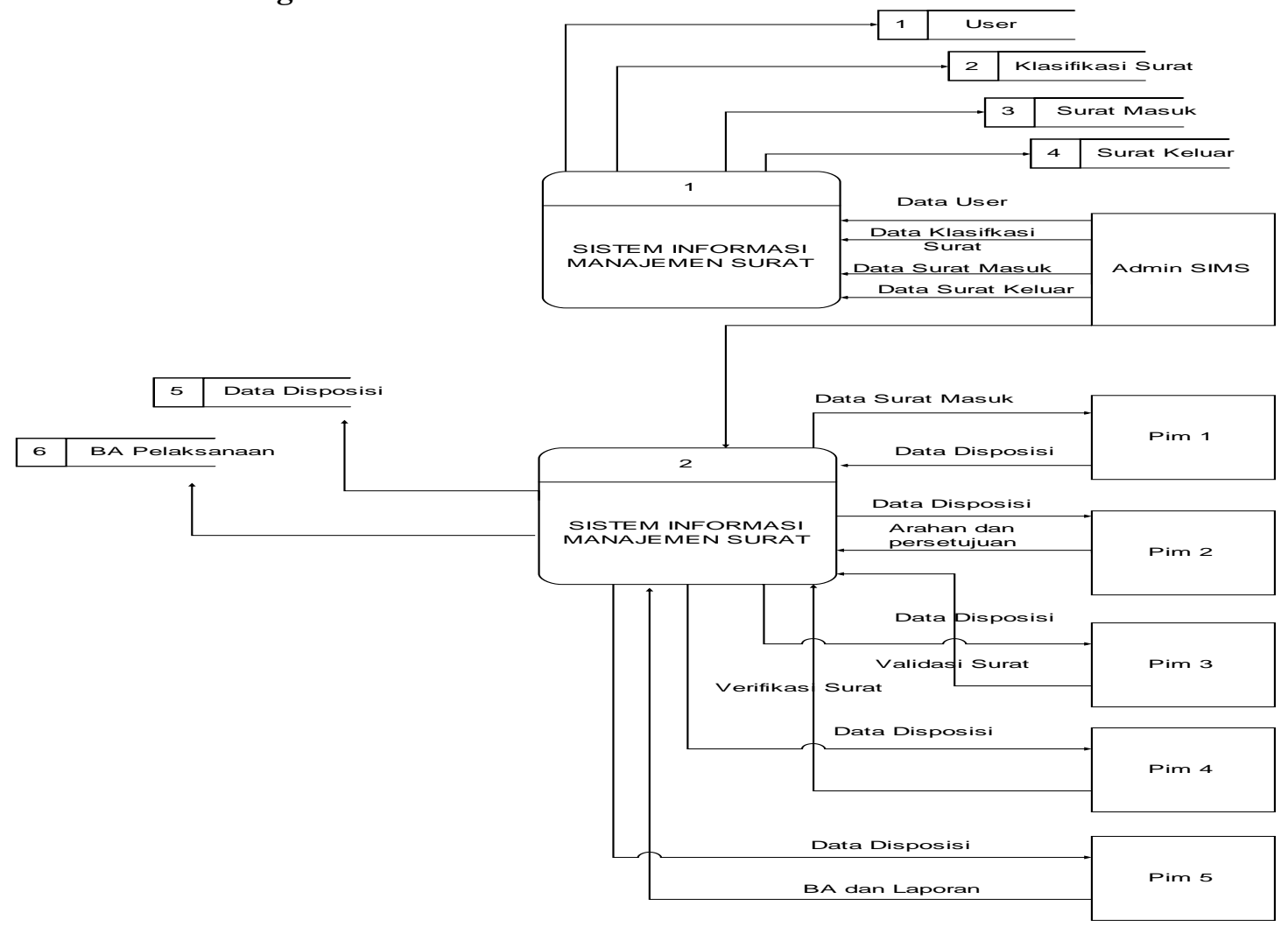

Gambar. 5 Data Flow Diagram

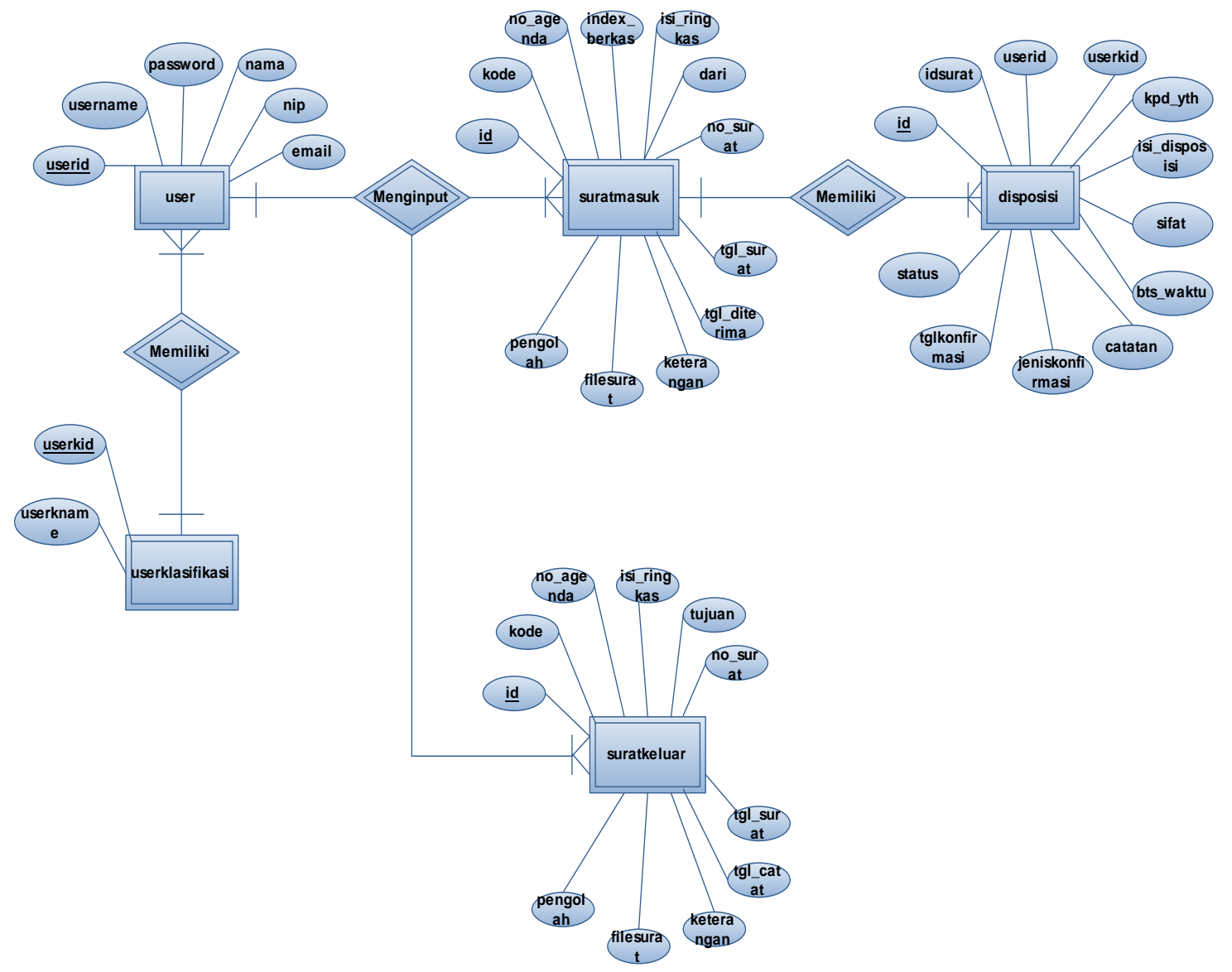

Gambar. 6 Entitas Relational Diagram (ERD) 


\subsection{Perancangan Database}

Pada tahap ini, dilakukan penyusunan dan perancangan database yang akan digunakan beserta strukturnya. Rancangan database sistem yang dibuat berupa Entity Relational Diagram (ERD), yaitu alat untuk merepresentasikan model data yang ada pada sistem dimana terdapat entity dan relationship dalam gambar. 6 .

\subsubsection{Struktur Basis Data danTabel}

Untuk mempermudah pengelolaan file basis data, digunakan Mysql. Sistem informasi biaya umum ini menggunakan satu buah file basis data bernama simansur.dbf.

Tabel 1. Tabel User

\begin{tabular}{|l|l|c|l|}
\hline \multicolumn{1}{|c|}{ Tyeld name } & \multicolumn{1}{|c|}{ Type } & $\begin{array}{c}\text { Field } \\
\text { Size }\end{array}$ & \multicolumn{1}{|c|}{ Description } \\
\hline userid & int & 11 & ID User \\
\hline userkid & int & 11 & Id Klas User \\
\hline username & Varchar & 20 & Nama User \\
\hline password & Varchar & 20 & Password User \\
\hline Nama & Varchar & 30 & Nama User \\
\hline Nip & Varchar & 25 & Nip User \\
\hline Email & Varchar & 25 & Email user \\
\hline status & int & 11 & \\
\hline
\end{tabular}

Tabel 2. Tabel user klasifikasi

\begin{tabular}{|l|l|c|l|}
\hline \multicolumn{1}{|c|}{ Field name } & \multicolumn{1}{|c|}{ Type } & $\begin{array}{c}\text { Field } \\
\text { Size }\end{array}$ & \multicolumn{1}{|c|}{ Deskripsi } \\
\hline Userkid & int & 11 & Id klasikasi user \\
\hline Userknama & Varchar & 30 & Nama klasifikasi \\
\hline
\end{tabular}

Tabel 3. Tabel surat masuk

\begin{tabular}{|l|l|c|l|}
\hline \multicolumn{1}{|c|}{ Field name } & \multicolumn{1}{|c|}{ Type } & $\begin{array}{c}\text { Field } \\
\text { Size }\end{array}$ & \multicolumn{1}{c|}{ Description } \\
\hline Id & int & 11 & Id surat masuk \\
\hline Kode & Varchar & 50 & Kode surat \\
\hline no_agenda & Varchar & 7 & Nomor agenda \\
\hline index_berkas & varchar & 12 & Index surat \\
\hline isi_ringkas & mediumText & & Isi surat \\
\hline Dari & Varchar & 250 & Asal surat \\
\hline no_surat & Varchar & 100 & $\begin{array}{l}\text { Nomor surat } \\
\text { masuk }\end{array}$ \\
\hline tgl_surat & Date & & Tanggal surat \\
\hline tgl_diterima & date & $\begin{array}{l}\text { Tanggal } \\
\text { penerimaan } \\
\text { surat }\end{array}$ \\
\hline keterangan & Varchar & 200 & Keterangan \\
\hline filesurat & Varchar & 200 & File scan surat \\
\hline status & Int & 11 & Status surat \\
\hline tanggal & datetime & & \\
\hline
\end{tabular}

Tabel. 4 Surat Keluar

\begin{tabular}{|l|l|c|l|}
\hline Field name & Type & $\begin{array}{c}\text { Field } \\
\text { Size }\end{array}$ & \multicolumn{1}{|c|}{ Description } \\
\hline id & int & 11 & Id surat keluar \\
\hline kode & Varchar & 50 & Kode surat \\
\hline no_agenda & Varchar & 7 & Nomor agenda \\
\hline isi_ringkas & $\begin{array}{l}\text { mediumT } \\
\text { ext }\end{array}$ & & Isi surat \\
\hline tujuan & Varchar & 250 & Tujuan surat \\
\hline no_surat & Varchar & 100 & Nomor surat keluar \\
\hline tgl_surat & Date & & Tanggal surat \\
\hline tgl_catat & date & & $\begin{array}{l}\text { Tanggal pengiriman } \\
\text { surat }\end{array}$ \\
\hline keterangan & Varchar & 200 & Keterangan \\
\hline File & Varchar & 200 & File scan surat \\
\hline pengolah & Int & 11 & Pengolah surat \\
\hline
\end{tabular}

Tabel .5. Tabel klasifikasi

\begin{tabular}{|l|l|c|l|}
\hline \multicolumn{1}{|c|}{$\begin{array}{c}\text { Field } \\
\text { name }\end{array}$} & \multicolumn{1}{|c|}{ Type } & $\begin{array}{c}\text { Field } \\
\text { Size }\end{array}$ & \multicolumn{1}{c|}{ Description } \\
\hline Id & int & 11 & Id klasifikasi \\
\hline kode & Varchar & 50 & Kode klasifikasi \\
\hline nama & Varchar & 250 & Nama klasifikasi \\
\hline uraian & Medium text & 12 & Uraian klasifikasi \\
\hline
\end{tabular}

Tabel 6. Tabel Disposisi

\begin{tabular}{|l|c|c|l|}
\hline \multicolumn{1}{|c|}{$\begin{array}{c}\text { Field } \\
\text { name }\end{array}$} & Type & $\begin{array}{c}\text { Field } \\
\text { Size }\end{array}$ & \multicolumn{1}{c|}{ Description } \\
\hline id & int & 11 & Id disposisi \\
\hline id_surat & int & 11 & id surat \\
\hline user_id & int & 11 & id surat \\
\hline userkid & int & 11 & Id klas user \\
\hline kpd_yth & varchar & 250 & Tujuan disposisi \\
\hline $\begin{array}{l}\text { isi_dispo } \\
\text { sisi }\end{array}$ & Varchar & 250 & isi disposisi \\
\hline sifat & enum & & Sifat surat \\
\hline $\begin{array}{l}\text { batas_wa } \\
\text { ktu }\end{array}$ & Date & & Batas waktu \\
\hline catatan & varchar & 250 & Catatan disposisi \\
\hline status & int & 11 & Status disposis \\
\hline
\end{tabular}

\section{Implementasi Sistem}

\subsection{Lingkungan Implementasi}

Implementasi aplikasi ini meliputi kebutuhan perangkat lunak, perangkat keras, form program yang sesuai, query yang digunakan, pemrograman dan pengujian program dan pengujian aplikasi yang telah dirancang sesuai dengan kebutuhan Insitut Seni Indonesia Padangpanjang.

\subsection{Lingkungan Perangkat Keras}

Perangkat keras yang diperlukan untuk keperluan menjalankan Sistem Informasi Manajemen Surat yang dibuat menggunakan aplikasi web dengan PHP dan MySql sebagai berikut:

1. Processor yang digunakan Intel ${ }^{\circledR}$ Cell ${ }^{\mathrm{TM}} 2$ Duo Processor T6600 (2.2 
GHz, 800 MHz FSB, 2 MB L2 cache)

2. Harddisk terpasang $250 \mathrm{~GB}$, rekomendasi minimum adalah $40 \mathrm{~GB}$

3. Memori (RAM) terpasang $1 \mathrm{~GB}$, rekomendasi minimum $512 \mathrm{MB}$

4. VGA Card terpasang $128 \mathrm{MB}$, rekomendasi minimum adalah $32 \mathrm{MB}$

5. Mouse dan Keyboard

6. Resolusi Layar Monitor 800 x 600

7. Printer

\subsection{Lingkungan Perangkat Lunak}

Dalam mendukung rancangan sistem ini selain dibutuhkan perangkat keras, dibutuhkan juga perangkat lunak yang digunakan sebagai pendukung untuk menjalankan aplikasi diantaranya adalah:

1. Sistem operasi windows 7

2. Software Xampp sebagai Web Hosting Local dan Database Mysql

\subsection{Hasil Implementasi}

Hasil perancangan ke dalam sebuah sistem dan aplikasi yang kemudian akan memperlihatkan output sebagai hasil implementasi.

a. Tampilan Utama dan Login sistem

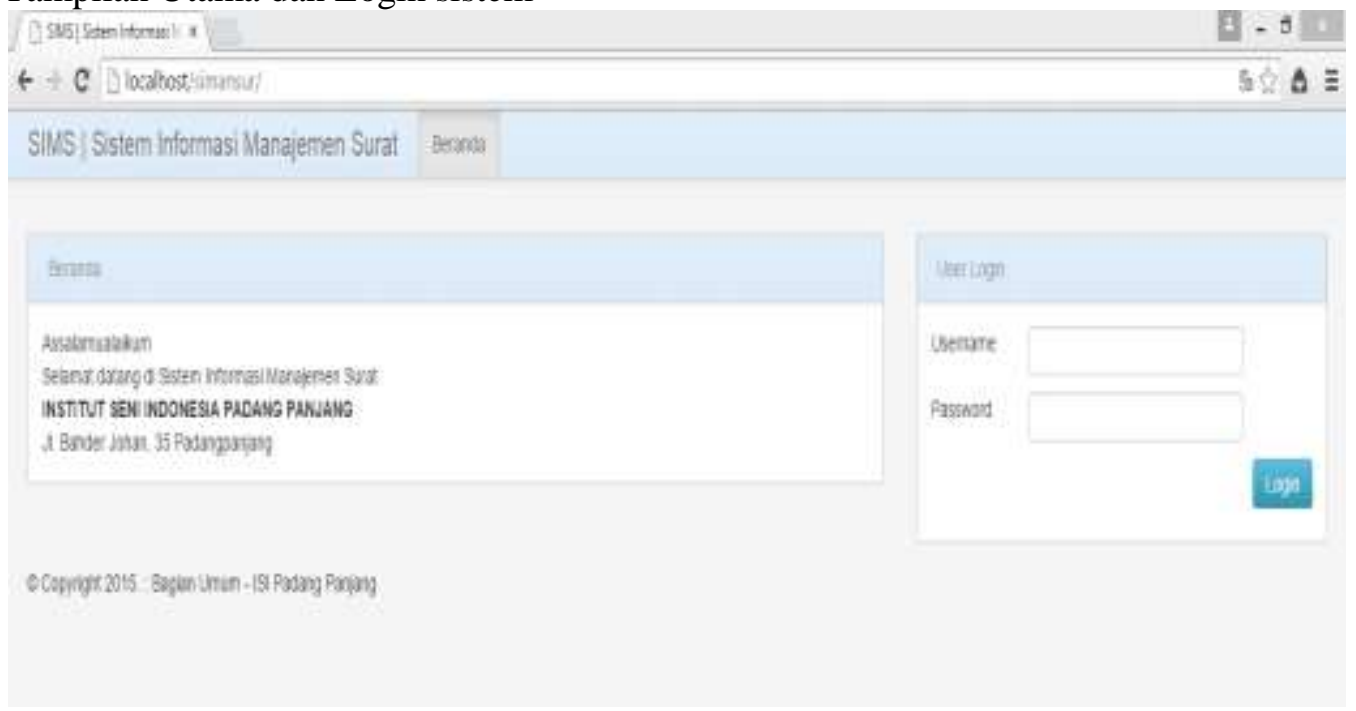

\section{Gambar. 7 Tampilan Utama dan Login sistem}

b. Tampilan Dashboard

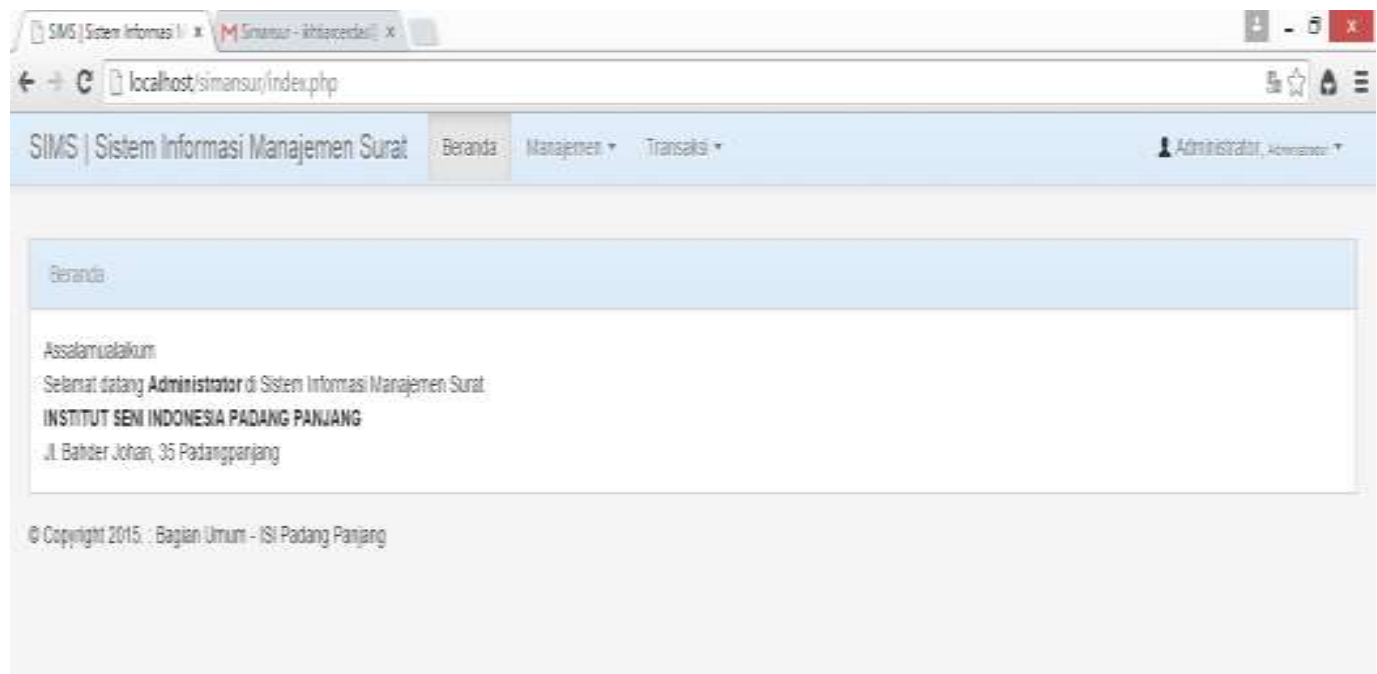

Gambar. 8 Tampilan Dashboard 
c. Tampilan Daftar Klasifikasi Surat

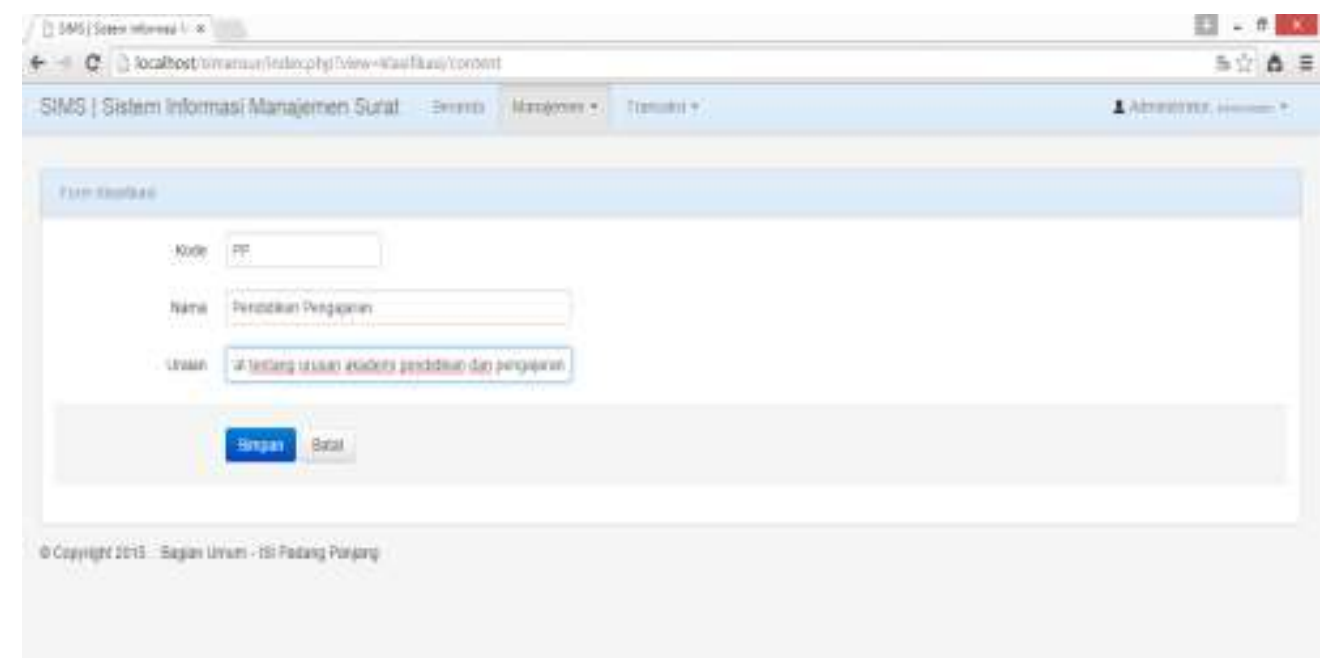

Gambar. 9 Tampilan Daftar Klasifikasi Surat

d. Tampilam Disposisi surat

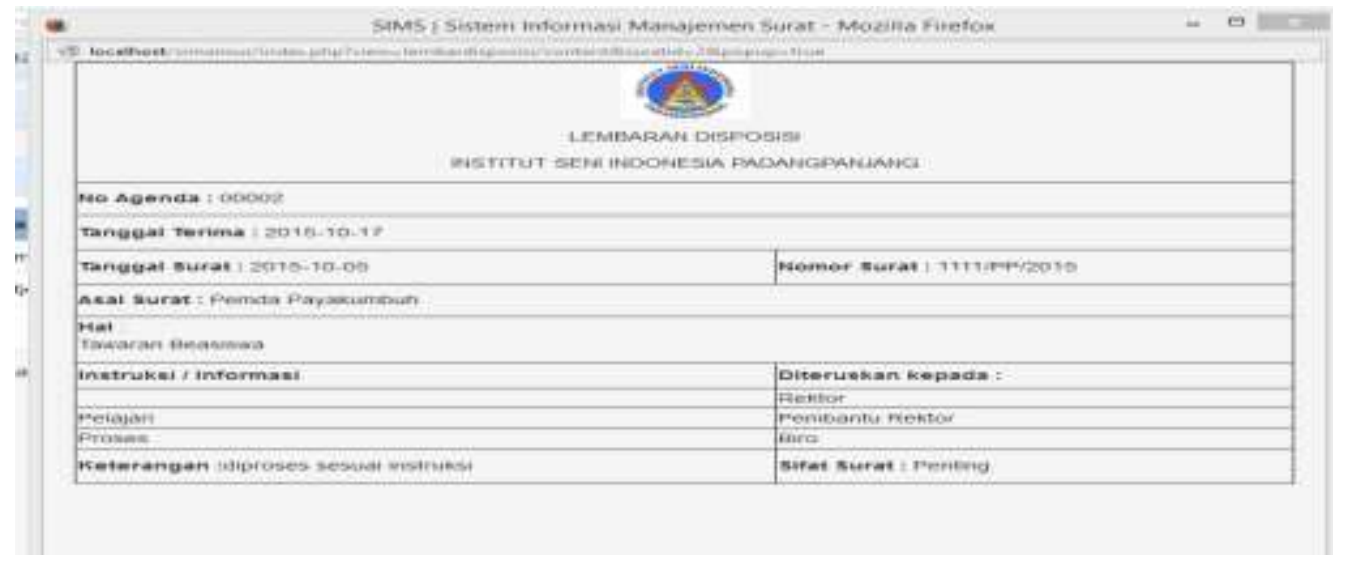

Gambar. 10 Tampilam Disposisi surat

e. Tampilan Laporan

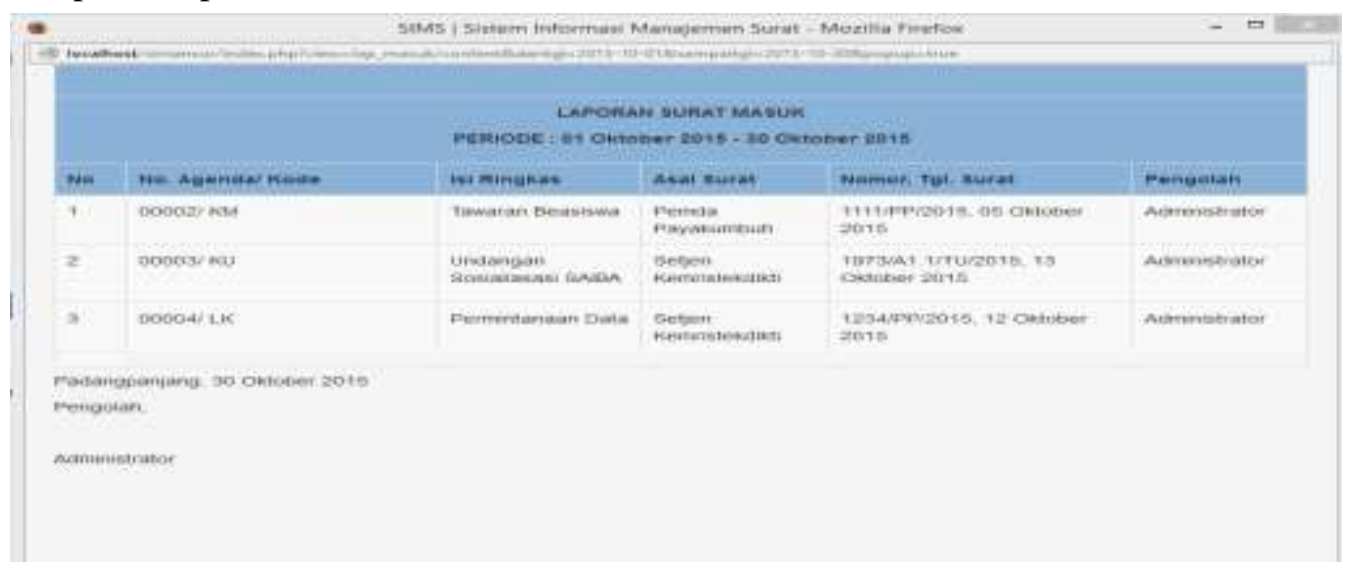

Gambar. 11 Tampilan Laporan 


\section{Kesimpulan}

Kesimpulan yang dapat diambil dari pembuatan Sistem Informasi Manajemen Surat di ISI Padangpanjang adalah sebagai berikut:

1. Berdasarkan hasil uji coba, Sistem Informasi Manajemen Surat (SIMS) dapat berjalan dengan baik sesuai dengan tata naskah dinas dilingkungan ISI Padangpanjang.

2. Sistem Informasi Manajemen surat dapat menggantikan fungsi buku agenda manual sebagai pencatat transaksi pengolahan surat.

3. Sistem yang dibangun dapat mengefektifkan pemakaian Alat Tulis Kantor dan penghematan anggaran.

\section{Daftar Pustaka}

Abdul, Kadir, Pengenalan Sistem Informasi, Penerbit Andi, Yogyakarta, 2003

Alwi, Hasan, Kamus Besar Bahasa Indonesia, Balai Pustaka, Jakarta, 2008

Community e Wolf, Buku Wajib Programer Indeks Lengkap Syntax, Mediakom, Yogyakarta 2012

Kementerian Pendayagunaan Aparatur Negara dan Reformasi Birokrasi, Peraturan Menteri nomor 80 tahun 2012 tentang
Pedoman Tata Naskah Dinas Instansi Pemerintah, 2012

Kementerian Pendidikan dan Kebudayaan, Peraturan Menteri nomor 6 Tahun 2013 tentang Tata Naskah Dinas dilingkungan Kementerian Pendidikan dan Kebudayaan, 2013

Kementerian Pendidikan dan Kebudayaan, Peraturan Menteri nomor 37 Tahun 2014 tentang Statuta Institut Seni Indonesia Padangpanjang, 2014

Kendall E Kennet dan Kendall E Julie, Analisis Dan Perancangan Sistem, PT INDEKS, Jakarta 2011

Loka Dwiartara. Ebook Menyelam dan Menaklukkan Samudera PHP http://www.ilmuwebsite.com

Lexy J Moelong, Prof, MA, Metode Penelitian Kualitatif Edisi Revisi, Remaja Rida Karya, Bandung 2011

Riko, Ervil, dkk, Panduan Penulisan dan Ujian Skripsi, Sekolah Tinggi Teknologi Industri Padang, 2013

Sakur B. Stendy, PHP 5 Pemograman Berorientasi Objek Konsep dan Implementasi, Penerbit ANDI, Yogyakarta 2010

Saifudin Azwar, MA, Metode Penelitian, Pustaka Pelajar, Yogyakarta, 2001 